\title{
Pastoralna orientacja teologii moralnej Bernharda Häringa
}

Przekonanie o. Häringa o konieczności pastoralnego ukierunkowania teologii moralnej miało dwie przyczyny. Pierwszą był faktyczny stan teologii moralnej, sposób jej nauczania i jej wpływ na posługę duszpasterską w pierwszej połowie XX wieku, drugą życie i wiara rodziny, z której wyszedł o. Häring. Te dwa fakty odcisnęły się w zasadniczy sposób na jego dalszym postępowaniu i nauczaniu.

\section{Rys historyczny teologii moralnej}

Jednym z mniej lubianych przez o. Bernharda przedmiotów w seminarium duchownym była teologia moralna. Powodem tego był zarówno sposób jej nauczania, jak i treść. Była to nauka oparta w całości na metodzie kazuistycznej. Poszczególne kazusy rozpatrywano na sposób jurydyczny, a to czyniło ją dyscypliną szkolną, oddaloną od realnego życia, uprawianą w oderwaniu od osoby działającej. Jej głoszenie przyczyniało się raczej do szerzenia 
strachu, który towarzyszył wielu wierzącym przez całe ich życie ${ }^{1}$. A przecież Jezus przyszedł na świat, aby ogłosić Dobrą Nowinę o miłości miłosiernej Boga, który jest Ojcem. Dobrze rozumieli to Apostołowie i pierwsi nauczyciele. Wierni posłaniu misyjnemu: „Idźcie na cały świat i nauczajcie wszystkie narody - uczcie je zachowywać wszystko, co wam powiedziałem" (Mt 28, 19-20), szli i nauczali; nauczali i głosili, co im Jezus przekazał. Życzeniem Jezusa jest przepowiadanie Jego nauki, kierowanej zarówno do poszczególnego człowieka, jak i całej ludzkości.

Aby nauka ta mogła dosięgnąć każdego i być przez niego przyjęta, konieczna jest nieustanna refleksja. Początkowo istniała tylko teologia ogólna, która usiłowała zgłębić Objawienie przyniesione przez Jezusa. Rozpatrywano poszczególne przypadki i zagadnienia, ale podejmowano również próby stworzenia syntezy całego nauczania, które miały być motywacją do postępowania wynikającego $\mathrm{z}$ bycia chrześcijaninem ${ }^{2}$.

Dalszy rozwój myśli i nauczania teologicznego ulegał nierzadko oddziaływaniu albo laksyzmu, albo rygoryzmu. Próby odnowy teologii podjęte przez Sobór Trydencki pozostały jednak pod wpływem metody kazuistycznej i ścisłego powiązania z obowiązującym prawem kanonicznym. Później pojawiło się oświecenie z jego usilnym podkreślaniem wartości umysłu, a wraz z nim głosy, że Objawienie w rozumieniu chrześcijańskim jest niezgodne z poznaniem rozumowym, zaś głoszone prawdy wiary pozbawione są podstaw naukowych ${ }^{3}$. Dotyczyło to także teologii moralnej.

1 Por. B. Häring, Meine Hoffnung für die Kirche. Kritische Ermutigungen, Freiburg 1997, s. 15.

2 Szczególną rolę odgrywają tutaj ojcowie Kościoła: św. Ambroży z De officiis, św. Augustyn z Enchiridion, De moribus.

3 Por. W. Tatarkiewicz, Historia filozofii, t. II, Warszawa 1958, s. 136-212. 
Z tymi skrajnymi postawami usiłował walczyć św. Alfons Liguori, proponując drogę złotego środka, tzw. ekwiprobabilizm4. Za podstawę swojego systemu moralnego przyjął on Objawienie i Tradycję, ale chętnie sięgał też do dyscyplin pozareligijnych. W swoim nauczaniu akcentował rolę sumienia, które przy orzekaniu w poszczególnych przypadkach ma opierać się na osądach rozumnych, pewnych i mądrych. Mimo tych usiłowań teologia moralna pozostała nadal kazuistyczna.

Również filozofia Kanta z jej poglądem heteronomicznym wywarła wpływ na dalszy rozwój myśli teologicznej ${ }^{5}$. Wysiłki te nie przyniosły jednak decydujących zmian. Do głosu dochodzi romantyzm, zwracając większą uwagę na uczucia, tradycję ludową, praktyki religijne. W nauczaniu moralnym ponownie podkreśla się teocentryzm i Objawienie. Stąd stosowana jest metoda historyczno-krytyczna, ale wykorzystywane są też osiągnięcia innych dyscyplin naukowych. Tego rodzaju działania przeciwstawiają się ciągle panującemu legalizmowi ${ }^{6}$.

Wpływy te dają się zauważyć zarówno w szkole tybińskiej, z jej przedstawicielem J.B. Hirscherem, jak i w nauczaniu J.M. Sailera. System moralny Sailera koncentruje się na zagadnieniach odejścia człowieka od Boga, czyli grzechu, na procesie powstawania, rozpowszechniania i skutkach grzechu. Następnie omawia drogę powrotu i pojednania, które jest nie tylko odwróceniem się od

4 Por. A. Liguori, Theologia moralis, Augustae Taurinorum 1879, s. 1 n.

5 Por. Ch. Keller, Die Disqualifizierung theologischer Moral durch die autonome Grundlegung der Ethik, w: tenże, Das Theologische in der Moraltheologie, Göttingen 1976, s. 19-86. Heteronomia moralna oznacza, że człowiek nie kieruje się w swoim działaniu prawem moralnym, które odkrywa w sobie, lecz prawem opartym na jakimś zewnętrznym autorytecie.

6 Por. A. Exeler, Eine Frohbotschaft vom christlichen Leben. Die Eigenart der Moraltheologie Johann Baptist Hirschers, Freiburg 1959, s. 290. 
grzechu, ale przede wszystkim radykalną zmianą życia i powrotem do stanu sprawiedliwości oraz pozostaniem i życiem w Bogu, co z kolei oznacza naśladowanie Chrystusa i działanie zgodnie z Jego duchem. Sailer pojmuje człowieka jako istotę rozumną i wolną, a dzięki sumieniu, które jest organem religijnym, człowiek doświadcza Boga jako najwyższego prawodawcy ${ }^{7}$.

Pewnego rodzaju nowością u Sailera jest to, że swój podręcznik teologii moralnej kieruje, tradycyjnie, w pierwszym rzędzie do księży i spowiedników jako duszpasterzy, ale także do światłych chrześcijan ${ }^{8}$.

Wysiłki zarówno św. Alfonsa, jak i Hirschera czy Sailera nie przyniosły większej odnowy teologii moralnej. Zarzucano im poważne błędy, przede wszystkim że nie uwzględniają aktualnej sytuacji, zachodzących przemian i wymogów, że za mało uwagi poświęcają szóstemu przykazaniu, że ich praca jest zbyt mało naukowa ${ }^{9}$. Następuje więc ponowny zwrot w stronę kazuistyki. Teologia moralna pozostaje $\mathrm{w}$ dalszym ciągu raczej katalogiem grzechów niż pomocą w realizacji chrześcijańskiej doskonałości.

W jej rozwoju można też znaleźć pozytywne punkty, jak zwrócenie większej uwagi na lepsze wykształcenie kleru, pogłębienie świadomości religijnej, próby oczyszczenia wiary z różnych zabobonów czy docenienie pobożności ludowej. Pojawiają się z czasem próby reform liturgii, katechezy czy duszpaster-

Por. H.J. Müller, Die ganze Bekehrung. Das zentrale Anliegen des Theologen und Seelsorgers J.M. Sailer, Salzburg 1956, s. 302 n.

8 Pełny tytuł brzmi: Handbuch der christlichen Moral, zunächst für künftige katholische Seelsorger und dann für jeden gebildeten Christen, t. 1-3, München 1817.

9 Por. E. Hirschbrich, Die Entwicklung der Moraltheologie im deutschen Sprachgebiet, seit der Jahrhundertwende, Klosterneuburg 1959, s. 16 n. 
stwa, większą wage przywiązuje się do Pisma Świętego, egzegezy, zauważona zostaje rola laikatu w Kościele ${ }^{10}$.

\section{Sylwetka o. Bernharda}

Taki stan teologii, duszpasterstwa i życia religijnego zastaje Bernhard, przychodząc na świat 10 listopada 1912 roku w Böbbingen. Jego dalsze życie, zwłaszcza życie wiary, jest ściśle powiązane $\mathrm{z}$ historią wielu ludzi, szczególnie jednak z historią głęboko i radośnie wierzących rodziców, którzy w duchu wzajemnego zrozumienia i partnerstwa przyjmowali wszystkie wydarzenia w świetle zdrowej wiary ${ }^{11}$. Częsta lektura Pisma Świętego, ale też innych książek o tematyce religijnej, przede wszystkim żywotów świętych, modlitwa w gronie rodzinnym, codzienne uczestnictwo w liturgii i przystępowanie do sakramentów świętych były dla tej rodziny oczywistością. Te praktyki rozbudzały w Bernhardzie chęć zostania kapłanem i misjonarzem. Dorastał do przekonania, że nie ma nic pilniejszego niż głoszenie Ewangelii, i to w dalekich krajach misyjnych. Fascynowali go przede wszystkim jezuici, misjonarze Azji: Mateusz Ricci i Franciszek Ksawery. Nie dziwi więc, że jego pierwotnym zamiarem było wstąpienie do tego zakonu. Jego zapał został jednak ostudzony, ponieważ uzdolnienia intelektualne predestynowały go do podjęcia studiów wyższych i pracy naukowej. Bernhard chce tego uniknąć za wszelką cenę. Dlatego kieruje kroki do redemptorystów, którzy obiecują mu po ukończeniu seminarium wyjazd na pracę misyjną do

10 Por. J. Pryszmont, Z historii teologii moralnej w ostatnich wiekach: $w$ kierunku odnowy, „Studia Theologica Varsaviensia” 21 (1983), nr 1, s. 7-51.

11 Por. B. Häring, Geborgen und frei. Mein Leben, Freiburg 1997², s. 7-11. 
Brazylii $^{12}$. Wstępuje więc do nowicjatu, odbywa studia filozoficzno-teologiczne i w maju 1939 roku przyjmuje święcenia kapłańskie. Już na jesieni zostaje jednak powołany do służby wojskowej i tym samym zmuszony do uczestnictwa w II wojnie światowej, m.in. na froncie wschodnim ${ }^{13}$.

Po przyjęciu święceń kapłańskich aktualna stała się sprawa wyjazdu na misję, rozumianą trochę stereotypowo jako głoszenie Ewangelii w dalekich krajach. Jednak grono profesorskie wymusiło na prowincjale skierowanie o. Bernharda na dalsze studia z argumentacją: „Oczekujemy, że zaangażujesz się na rzecz gruntownej odnowy teologii moralnej”14. Konieczność taka była ewidentna i paląca. Wielu biskupów wysyłało nadal kapłanów na studia prawa kanonicznego, także do Rzymu, aby w ten sposób przygotować ich do podjęcia pracy wykładowców teologii moralnej. O. Häring nie wyjeżdża więc na misję, ale staje się głosicielem Słowa i temu powołaniu pozostaje wierny do końca swojego życia.

W 1947 roku kończy doktorat i podejmuje wykłady w Gars am Inn. Już w tym czasie udziela się duszpastersko zarówno w okolicznych parafiach, jak i na pracach misyjnych (misje ludowe). Bierze czynny udział w przygotowaniach do tych ostatnich szczególnie poprzez głoszenie rekolekcji do księży. Ważnym doświadczeniem pastoralnym były misje dla imigrantów. Pierwsza tego rodzaju praca miała miejsce w okolicach Coburga ${ }^{15}$. Polegała na odwiedzaniu poszczególnych miejscowości, również w celu

12 Por. M. Leitgöb, Bernhard Häring. Kirche im Zeichen der Barmherzigkeit, Innsbruck 2015, s. 17 n.

13 Por. B. Häring, Geborgen und frei, dz. cyt., s. 15 n.

14 M. Leitgöb, Bernhard Häring, dz. cyt., s. 19.

15 Por. B. Häring, Heute Priester sein. Eine kritische Ermutigung, Freiburg $1996^{2}$, s. 19. 
pozyskania ludzi świeckich jako współpracowników. Nabożeństwa odbywały się następnie w wynajmowanych salach. Spotkania te uświadomiły mu bardzo mocno, że głoszenie Słowa musi być poprzedzone uważnym wsłuchiwaniem się w problemy i bolączki ludzi. Sam wyznaje, że nie sięgnął po uprzednio starannie przygotowane kazania, ale koncentrował się na usłyszanych problemach, obawach i lękach, jak i nadziejach uczestników i starał się udzielić na nie odpowiedzi ${ }^{16}$.

Wyczuwając potrzebę czasu, redemptoryści, z inicjatywy ówczesnego generała Leonarda Buijsa, otwierają akademię (Accademia Alfonsiana) w Rzymie. Ma ona kształcić przyszłych moralistów najpierw dla własnego instytutu, ale także na rzecz całego Kościoła. Dla inicjatorów tego dzieła, a należał do nich także o. Häring, było jasne, że nauki biblijne i humanistyczne muszą stanowić fundament teologii moralnej. W 1950 roku o. Häring rozpoczyna pracę $\mathrm{w}$ tej akademii jako wykładowca ${ }^{17}$. Zarówno w czasie przedsoborowym, jak i w trakcie Soboru Watykańskiego II jest już postacią dominującą w dziedzinie teologii moralnej.

\section{Pastoralny rys teologii moralnej o. Häringa}

Życie i nauczanie o. Häringa było ciągłym angażowaniem się w szeroko pojętą posługę duszpasterską. To zaangażowanie oraz pozyskane w ten sposób doświadczenia miały wpływ na jego pracę naukową. Zawsze podkreślał, że teologia musi być przeżywana i tworzona przede wszystkim w jej wymiarze pastoralnym ${ }^{18}$.

\footnotetext{
16 Por. tenże, Geborgen und frei, dz. cyt., s. 110.

17 Por. tamże, s. 57.

18 Por. tamże, s. 105.
} 
Musi być pomocą życiową, zwróconą w stronę człowieka. Nic, co ludzkie, nie może być Kościołowi obce, i tylko w takim przypadku może on głosić człowiekowi zbawienie w każdej sytuacji jego życia. Dlatego o. Bernhard podchodził do problematyki moralnej w sposób bardzo życiowy i bezpośredni ${ }^{19}$.

Jego zamiarem było ukazać życie chrześcijańskie jako coś szczególnego, jednorazowego, wypełnionego bogactwem łaski i prawdy Bożej. Chciał, aby jego teologia moralna była teologią „przepowiadania”, by była ściśle związana z teologią pastoralną. Obydwie dziedziny muszą pozostawać w stosunku do siebie otwarte i wzajemnie się warunkujące. Co wypracuje teologia moralna, powinno następnie być wprowadzane w życie w konkretnej sytuacji poszczególnej osoby i całego społeczeństwa $^{20}$. O. Häring opowiadał się więc za typem teologii liturgiczno-sakramentalnym ${ }^{21}$. Było dlań jasne, że rzeczywistość stała się o wiele bardziej złożona, więc i teologia musi ujmować człowieka i jego życie całościowo. Nie chciał, aby jego teologia moralna miała charakter akademicki. Uważał, że nauczanie ma sens tylko wówczas, gdy jego adresaci stają się „współsprawcami”, współtwórcami. Był przekonany, że teologia moralna nie jest czymś statycznym; jest ona teologią życia w Chrystusie. Dlatego musi ukazywać w całej rozciągłości obszar postępowania zawartego pomiędzy dolną granicą dobra a górną granicą doskonałości. Jest nieustannym staraniem się o lepsze rozumienie, czym jest naśladowanie Chrystusa.

19 Por. V. Schurr, Bernhard Häring. Die Erneuerung der Moraltheologie, Salzburg 1970, s. 9-30.

20 Por. M. Leitgöb, Bernhard Häring, dz. cyt., s. 87.

21 Por. B. Häring, Das Gesetz Christi. Moraltheologie dargestellt für Priester und Laien von Bernhard Häring, Freiburg 1954, s. 1326-1328. 
Doświadczenia duszpasterskie uświadomiły mu bardzo wyraźnie, że nauczanie moralne ma uzmysłowić odbiorcy, iż Bóg wyzwala go w Chrystusie do prawdziwego życia. Dokonuje tego mocą łaski i miłości. Zarazem o. Häring przestrzegał, że nawet jeżeli jego teologia moralna prezentuje wysoko postawiony ideał, to nie może to oznaczać usprawiedliwienia dla rygoryzmu.

W metodzie naukowej zrezygnował z podziału scholastycznego. Uwidacznia się tutaj wpływ szkoły tybińskiej i prof. Steinbüchela, u którego pisał pracę doktorską. O. Häring pojmował teologię moralną jako połączenie dogmatyki z życiem codziennym. W centrum stoi idea królestwa Bożego jako miłości. Ubolewał, że do tej pory teologię moralną warunkowały przepisy prawa, dlatego była ona pozbawiona radości bycia w służbie Pana, powodowała zubożenie duchowe, a nawet przyczyniała się do powstawania chorych osobowości. Blokując radość, czyniła ludzi spiętymi i pozbawionymi entuzjazmu życia. W nauczaniu akcentowano najpierw przepisy prawne i ich bezwarunkową obowiązywalność pod groźbą grzechu ciężkiego, a dopiero w drugiej kolejności mówiono o przebaczeniu. Zapominano jednak, że aby móc wypełnić prawo, konieczna jest łaska. Człowiek, który tego doświadczy, staje się sługą radości, a radość wypływająca z uczestnictwa w Bogu jest życiodajną siłą. Obejmuje ona następnie relację do Boga i do bliźniego, a tym samym przyczynia się w dalszej kolejności do nawracania poszczególnych ludzi i całego społeczeństwa. Dlatego tak ważne jest osobiste doświadczenie łaski jako Dobrej Nowiny. Dopiero na takim fundamencie może być mowa o prawie ${ }^{22}$. O. Häring usilnie akcentował wolność

22 Por. tenże, Geborgen und frei, dz. cyt., s. 65; tenże, Ist die Moraltheologie des hl. Alfonsus aktuell?, w: tenże, Die gegenwärtige Heilsstunde. Gesammelte Aufsätze von Bernhard Häring, Freiburg 1964, s. 50-72. 
człowieka, a nie tylko posłuszeństwo wobec prawa i autorytetów. Na pierwszym miejscu stawiał bezwarunkowe „tak” dla porządku łaski, dla ewangelicznej radości i tym samym „tak” dla uzdrowienia całego człowieka ${ }^{23}$. To Bóg wychodzi człowiekowi naprzeciw i w Jezusie Chrystusie zaprasza go do nawrócenia, albowiem bliskie jest królestwo niebieskie (por. Mt 4, 17).

Teologia moralna o. Häringa miała charakter chrystocentryczny. „Normą, centrum i celem chrześcijańskiej teologii moralnej jest Chrystus. Prawem chrześcijanina nie jest nikt inny jak sam Chrystus, gdyż tylko On jest naszym Panem, naszym Odkupicielem. W nim żyjemy naszym życiem i On jest naszym prawem" ${ }^{24}$. W teologii moralnej patrzył więc na Boga i człowieka z punktu widzenia Chrystusa. Tego rodzaju spojrzenie jest twórcze i zarazem wolne w wierności.

O. Häring starał się dostrzegać dobro w człowieku i obdarzać go daleko idącym zaufaniem. „Kto pojmuje siebie jako rozpoznanego przez Jezusa, ten może odetchnąć, ten może się podnieść $\mathrm{z}$ duchowego paraliżu" ${ }^{25}$. W tym ujęciu człowiek jest istotą społeczną, historyczną, religijną i kultyczną. Dlatego o. Bernhard podkreślał ważność modlitwy i życia sakramentalnego. Tradycyjnie w pierwotnym Kościele nauczanie moralne łączono z przygotowaniem do sakramentów. Później jednak porzucono tę praktykę, a na miejsce nauki moralnej wprowadzono prawo kanoniczne. Od tej pory teologia moralna, mimo wszystko,

23 Por. tenże, Frei in Christus. Moraltheologie für die Praxis des christlichen Lebens, t. I: Das Fundament aus Schrift und Tradition, Freiburg 1979, s. 19; tenże, Geborgen und frei, dz. cyt., s. 68.

24 Tenże, Das Gesetz Christi, dz. cyt., s. 39.

25 Tenże, Es geht auch anders. Plädoyer für eine neue Umgangsform in der Kirche, Freiburg 1993, s. 15. 
była nauką w typie kazuistyczno-kanonicznym. W przeważającej mierze dotyczyła konfesjonału. Dokonywała wyliczeń poszczególnych praw i obowiązków. Ujawniał się tu brak dojrzałej, ugruntowanej wiary. Charakterystyczne, że podręczniki teologii moralnej zawierały podtytuł: „według norm prawa kanonicznego”. Dopiero Pius X i ruchy liturgiczne skorygowały trochę to podejście i wskazały na źródło łaski i mocy życia nadprzyrodzonego. Powróciło ukierunkowanie chrystocentryczne i teocentryczne. Podkreślano, że sakramenty uświęcają życie i wprowadzają je w blask świętości Boga. Dokonuje się więc dialog osobowy. Również Sobór Watykański II podkreślił znaczenie sakramentalne i chrystocentryczne teologii moralnej. Dlatego tajemnica wcielenia, życia, śmierci, zmartwychwstania i paruzji Chrystusa stanowią sedno jego spojrzenia na życie osoby ludzkiej, którą o. Häring pojmował zawsze zarówno jako jednostkę, jak i społecznośćc ${ }^{26}$.

O. Häring był przekonany, że chrystocentryzm prowadzi do wspólnoty. Kto postawi Chrystusa w centrum swojej uwagi i naśladuje Go, ten automatycznie wchodzi do wspólnoty ze wszystkimi, którzy czynią to samo, i staje się gotowy wraz z nimi uczyć się i wrastać coraz głębiej we wspólnotę z Chrystusem. On daje udział w wyzwalającej prawdzie, a ta prawda prowadzi do bliźniego. Z Chrystusem i w Chrystusie staje się człowiek solą ziemi i światłem świata ${ }^{27}$. O. Häring usilnie starał się, aby jego teologia pozostawała na służbie życiu, którego podstawy znajdują się w Biblii. Jest ono darem i jako takie jest wolne, jest wolnością.

26 W tym temacie o. Häring powołuje się na naukę encykliki Mystici Corporis Christi z jej wezwaniem do troski o osobę indywidualną i całą społeczność; por. AAS 35 (1943), s. 193-248. Por. tenże, Moraltheologie im Umbruch, w: tenże, Die gegenwärtige Heilsstunde, dz. cyt., s. 15-24.

27 Ten temat jest głównym motywem tomu trzeciego Frei in Christus. 
Jego twórcza i odpowiedzialna moc objawia się temu, kto decyduje się na relację z Panem. Tak pojęta teologia staje się teologią odpowiedzialności w oparciu o koncepcję powołania chrześcijańskiego. Dlatego za cechę specyficzną życia i postępowania chrześcijanina o. Häring uważał jego osobiste powołanie w i do wolności oraz jego wierną odpowiedź na nie. Prawdziwe chrześcijańskie życie przynagla do miłości Jezusa Chrystusa i bliźniego w Chrystusie. Ta miłość jest odpowiedzią na Jego miłość i tej miłości trzeba się ciągle na nowo uczyćc ${ }^{28}$. O. Häring zauważał, że prawem chrześcijanina jest życie w Chrystusie, który obdarowuje człowieka swoim życiem w Duchu Świętym, w Duchu prawdy i miłości ${ }^{29}$.

Ciągle podkreślał, że teologia nie jest i nie może być czymś statycznym, że musi uwzględniać rozwój i zachodzące zmiany i w ich świetle szukać odpowiedzi na palące problemy. W przeciwnym razie nie spełni swojego zbawczego zadania. Wskazywał też, że nie wolno jej zerwać ze zdrową i czystą tradycją i przestać ją kontynuować. Musi ona usilnie zgłębiać swoje źródła i swój rozwój historyczny, zwracać baczną uwagę na współczesne potrzeby i pozostając zawsze wierną sobie, poszukiwać odpowiedzi na obecne wyzwania. W tym celu konieczna jest dobra znajomość uwarunkowań danego miejsca i czasu, a w przekazie treści trzeba się posługiwać językiem danej epoki. To przyczyni się do adekwatnego nauczania. Tak uprawiana teologia stanie się latarnią ukazującą właściwy kierunek i zarazem pozostanie w służbie zbawienia przy pełnej otwartości na potrzeby i wymogi czasu ${ }^{30}$.

28 Por. A. von Liguori, Jesus lieben lernen, Freiburg 1990, s. 15.

29 Por. B. Häring, Das Gesetz Christi, dz. cyt., s. 1326 n.

30 Tenże, Die katholische Moraltheologie in der Begegnung mit dem Zeitgeist, w: tenże, Die gegenwärtige Heilsstunde, dz. cyt., s. 34-49. 
Po 25 latach od ukazania się Das Gesetz Christi powstało Frei in Christus. Nie chodziło w nim o odrzucenie lub wyparcie się pierwszego dzieła. Dokonało się jednak wiele zmian i nastąpił rozwój myśli teologicznej. O. Häring przyznaje, że sam jest członkiem Kościoła pielgrzymującego i uczestniczy w procesie jego uczenia się. Jego bogate doświadczenia, kontakty, a zwłaszcza doświadczenie Soboru Watykańskiego II i czasu po nim, zmotywowały go do tej pracy. Ufał, że nowe dzieło będzie w większym stopniu odpowiadało uniwersalizmowi chrześcijaństwa, że jeszcze bardziej uwidoczni chrystocentryzm, że nie będzie propagowało tylko etyki postawy, ale o wiele bardziej etykę odpowiedzialności, że pozostanie wierną nauczaniu Kościoła, ale nie w sensie statycznym, lecz bardziej wyakcentuje twórczy wymiar wolności $\mathrm{w}$ wierności ${ }^{31}$.

W skrócie można więc powiedzieć, że wszystko w jego teologii moralnej kręciło się wokół życia - nie tylko w sensie postaw i zachowań. Przede wszystkim chodziło mu o „formowanie dojrzałej, zdolnej do podejmowania decyzji osobowości chrześcijańskiej (...) o troskę o dobre drzewo w nadziei, że przyniesie ono dobry owoc"32.

\section{Adresaci}

Zamiarem o. Häringa było formowanie chrześcijańskiej osobowości zarówno każdego indywidualnego człowieka, jak i całej wspólnoty. Chciał, aby było to wychowanie do dojrzałości religijnej i moralnej. Swoje pierwsze wielkie dzieło z zakresu teologii

31 Por. tenże, Frei in Christus, t. I, dz. cyt., s. 17.

32 Tamże, s. 331. 
moralnej, Das Gesetz Christi ${ }^{33}$, zaadresował na wzór J.M. Sailera do kapłanów i ludzi świeckich. Dlatego też dobierał odpowiedni sposób wyrażania przekazywanych treści, chcąc pomóc w łatwiejszym zrozumieniu chrześcijańskiej moralności świeckim, których uważał za współodpowiedzialnych towarzyszy drogi ${ }^{34}$, a kapłanom oferował pomoc w głoszeniu i nauczaniu podstawowych prawd moralnych. We wprowadzeniu do Das Gesetz Christi podkreślił bardzo zdecydowanie, że nie było jego zamiarem napisanie teologii moralnej jako podręcznika dla spowiedników, którzy rozumieją swoje powołanie jako sędziowie w konfesjonale, ale dla ludzi będących w drodze.

Jego teologia moralna we wszystkich aspektach usiłuje więc nawiązać żywy kontakt ze współczesnymi wiernymi, aby następnie razem z nimi udać się we wspólną drogę ${ }^{35}$. Treści zawarte w Das Gesetz Christi w rozdziałach o decyzji fundamentalnej (5), sumieniu (6) czy grzechu i nawróceniu (8) stanowią materiał do owocnego przepowiadania. O. Häring formułował swoje poglądy tak, aby mogły służyć praktycznie zarówno kapłanom, jak i świeckim.

\section{a) Kapłani}

Na pierwszym miejscu jako adresatów swojego dzieła Das Gesetz Christi o. Häring wymienił kapłanów. Wpływ na to miało jego osobiste doświadczenie z proboszczem rodzinnej parafii,

33 Tytuł dla Das Gesetz Christ zaczerpnął z Rz 8, 1-2: „Teraz jednak dla tych, którzy są w Chrystusie Jezusie, nie ma już potępienia. Albowiem prawo Ducha, który daje życie w Chrystusie Jezusie, wyzwoliło cię spod prawa grzechu i śmierci”.

34 Por. B. Häring, Frei in Christus, t. I, dz. cyt., s. 20-22.

35 Por. tamże, s. 74. 
raczej negatywne, jak i spotkania $\mathrm{z}$ różnymi kapłanami w późniejszym życiu. Niestety, doświadczenia te odzwierciedlały faktyczny stan kapłaństwa z czasów przedsoborowych. Swoją teologię moralną zaproponował im więc jako odpowiedź na ich obawy i lęki, jako pomoc dla ich często niepewnych sumień. W tym przypadku pozostał wierny św. Alfonsowi, którego aktualność nauczania została w tych latach potwierdzona przez ogłoszenie go patronem spowiedników, jak i wszystkich, którzy słowem i pismem służą przekazowi teologii moralnej ${ }^{36}$.

O. Häring uważał, że zagadnienie sumienia musi znaleźć odpowiednie miejsce $\mathrm{w}$ przepowiadaniu i nauczaniu moralnym. Ciągle należy apelować i zwracać się do sumienia odbiorcy, chociaż nie wolno go przy tym ani zniewalać, ani zwalniać z odpowiedzialności. Swoją pracą usiłował więc wspierać i motywować zarówno kapłanów, jak i świeckich do konsekwentnego postępowania według poprawnie uformowanego sumienia, do odważnego kroczenia czasami nowymi drogami, ale zawsze w świetle wiary i wierności. Za bardzo ważne uważał w tym kontekście kształcenie duszpasterzy, ponieważ to oni mają przejąć odpowiedzialność za powierzony im lud. Do tego zadania muszą być odpowiednio przygotowani; muszą coraz bardziej upodabniać się do Chrystusa, najwyższego Pasterza ${ }^{37}$.

O. Häring zdawał sobie sprawę, że wysiłki Soboru Trydenckiego w celu odnowy kapłaństwa były ważne. Zwrócono wówczas większą uwagę na ogólną formację kleru, ale pozostała ona nadal bardzo schematyczna, dla wszystkich jednakowa, jednakowe były idee i w pewnym sensie „ideologie”. Położono wielki nacisk

Por. AAS 42 (1950), s. 595.

37 Por. M. Leitgöb, Bernhard Häring, dz. cyt., s. 65. 
na poznanie podstawowych prawd wiary. Księża mieli wiedzieć, co jest oficjalną nauką Kościoła, jakie są ich zadania, obowiązki i prawa, co stosować w posłudze kapłańskiej ${ }^{38}$. Było to więc ujęcie legalistyczne, które w wielu przypadkach prowadziło do chorobliwego posługiwania, bo jeżeli sprawy najbardziej banalne uznawano za grzech śmiertelny, jeżeli wszystkie nakazy i zakazy były wiążące w każdej sytuacji i nie dopuszczały żadnych wyjątków ani rozróżnień, nawet gdy stały w sprzeczności z innymi przykazaniami, to musiało to odbijać się negatywnie na życiu wiernych, stając się przyczyną strachu i tym samym tworząc religię strachu. Doświadczenia pastoralne, a także sanitarne czasu wojny uświadomiły o. Häringowi, że obowiązkiem kapłana jest bycie moralistą, ale w sensie terapeutycznym ${ }^{39}$. Teologia moralna musi wyzwalać do radości bycia z Bogiem, do radości służby Bogu i bliźniemu. Ma równać drogi do zdrowych, uzdrawiających relacji osobistych i strukturalnych.

Ważnym krokiem w tym kierunku były zalecenia Soboru Watykańskiego II, aby dokonać dalszych reform seminariów duchownych według nowego rozumienia kapłaństwa i Kościoła ${ }^{40}$. Zalecenia te podnoszą również kwestię teologii moralnej. Ma ona być obficie karmiona Pismem Świętym, ukazywać doniosłość powołania chrześcijańskiego w Chrystusie i związanych z nim obowiązków, aby przynosić owoc w miłości za życie świata ${ }^{41}$.

38 Por. B. Häring, Heute Priester sein, dz. cyt., s. 73-74.

39 Por. tenże, Frei in Christus. Moraltheologie für die Praxis des christlichen Lebens, t. III: Die Verantwortung des Menschen für das Leben, Freiburg 1981, s. 17-18.

40 Dyrektywy te można znaleźć w konstytucji Lumen gentium oraz w dekrecie Presbyterorum ordinis.

${ }^{41}$ Por. Dekret o formacji kapłańskiej Optatam totius, nr 16. 
O. Häring słusznie uważał, że kapłani będą mogli służyć ludziom, jeżeli poznają warunki ich życia, ich radości i troski. Muszą być zakorzenieni w środowisku, dla którego pracują. Musi ich cechować szczególna bliskość względem ludzi, aby mogli odpowiadać na ich problemy tu i teraz i aby głoszona przez nich Ewangelia była aktualna. Dlatego muszą być czujni na znaki czasu i mieć ducha rozróżniania. Ważne jest tutaj osobiste rozmodlenie. Modlitwa otwiera na Ducha Świętego i Jego światło. Nie oznacza to przyzwolenia na opieszałość. Chrześcijanin musi współpracować z łaską za pomocą wszystkich dostępnych mu środków. Duch Święty obdarza zaufaniem i mocą, ale nie usprawiedliwia ani powierzchownego optymizmu, ani dogłębnego pesymizmu. Dlatego kapłani muszą zwracać uwagę na pozytywne znaki obecności Boga, jak i na wszelkie znaki zła i zagrożeń. Przepowiadanie jest odpowiedzią na te znaki i musi być życiowym ukazywaniem woli Bożej. Jako uczniowie Chrystusa, mają głosić w porę i nie w porę (por. $2 \mathrm{Tm} 4,2$ ), wykorzystując wszystkie sposobności ku temu. Odnosi się to do wiary, ale też ekologii, gospodarki czy polityki ${ }^{42}$.

Bardzo zdecydowanie sprzeciwiał się tezie, że religia jest sprawą prywatną. Uważał to zasadniczo za obrazę Boga, gdyż takie ujęcie zaprzecza wspólnotowemu charakterowi religii, jej odpowiedzialności za wspólnotę, która niestety w wielu przypadkach uległa laicyzacji. Podkreślał więc, że każdy chrześcijanin jest odpowiedzialny za życie $\mathrm{w}$ społeczeństwie, za tworzenie atmosfery i przekonań, także politycznych. $\mathrm{W}$ duchu poszanowania

42 Por. Presbyterorum ordinis, nr 22; B. Häring, Frei in Christus. Moraltheologie für die Praxis des christlichen Lebens, t. II: Der Weg des Menschen zur Wahrheit und Liebe, Freiburg 1980, s. 241, oraz t. III, dz. cyt., s. 17-18. 
wolności przyznawał, że nikt nie może drugiemu narzucać przekonań religijnych wbrew jego poglądom, sumieniu. W tym kontekście próbował jednak ukazywać odpowiedzialność człowieka za świat, za wiarę, politykę, ekologię, prawdę. To wszystko wywiera wszak ogromny wpływ na całe społeczeństwo. Dlatego całość życia chrześcijańskiego powinna charakteryzować solidarność ze wspólnotą ${ }^{43}$.

O. Häring uważał, że głównym celem duszpasterskiej posługi kapłanów jest niesienie pomocy wiernym w ich drodze do dojrzałości chrześcijańskiej. Do ich najważniejszych zadań należy troska o ludzi starszych, chorych, umierających, a także z rodzin rozbitych, rozwiedzionych, ponownie pobranych. Do dalszych - pielęgnacja życia wspólnotowego pomiędzy prezbiterami. Chodzi o wzajemną pomoc i zrozumienie, szczególnie pomiędzy pokoleniami kapłanów starszych i młodszych. Chociaż tradycja jest ważna, to jednak nie może ona zniewalać, ale ma raczej inspirować do dalszego rozwoju. Nie wolno kapłanom patrzeć z nostalgią na minione lata, lecz muszą stawiać czoła obecnym wyzwaniom i z pełną odpowiedzialnością spoglądać w przyszłość. Kapłaństwo nie może być rozumiane jako kariera, prestiż czy wyniosłość, legalizm w przepowiadaniu i nauczaniu, chęć kontroli i moralizatorstwo, dążenie do władzy i posiadania. Dlatego kapłani muszą ciągle stawiać pod znakiem zapytania swój sposób życia i postępowania, wsłuchiwać się uważnie w słowo Boże, w głos Kościoła i analizować styl swojej posługi duszpasterskiej ${ }^{44}$. Ważną rolę musi odgrywać Eucharystia. Ona

43 Por. B. Häring, Die katholische Moraltheologie in der Begegnung mit dem Zeitgeist, dz. cyt., s. 34-49.

44 Por. tenże, Heute Priester sein, dz. cyt., s. 125. 
stanowi centrum wspólnoty chrześcijańskiej, a z tym związana jest troska o zbawienie każdego człowieka ${ }^{45}$.

Kluczem do poprawnego zrozumienia roli i zadań kapłana według o. Häringa jest Jezus jako Sługa Pański. Odwołuje się on tutaj do znanej pieśni Sługi Pańskiego z Księgi proroka Izajasza (Iz 42 n.). Ta postawa Jezusa ujawnia się już w Jego chrzcie, który jest uwielbieniem Ojca, a także pożytkiem dla ludu. Jezus zostaje namaszczony Duchem Świętym i uzdolniony do wyrażenia „tak” wobec woli Ojca, wobec swojego powołania i posłania. Konkretyzacja tego dokonuje się w umyciu nóg uczniom, ustanowieniu Eucharystii i w śmierci krzyżowej. Jest to czytelny znak, że Jezus przyszedł nie po to, aby Mu służono, ale żeby służyć ${ }^{46}$. W tym duchu mają też żyć i posługiwać kapłani.

Pastoralne ukierunkowanie o. Häringa i jego troska o kapłanów nie pozostały niezauważone. To, że ma on tutaj coś ważnego do powiedzenia, dostrzegł papież Paweł VI. W 1964 roku zaprosił o. Häringa do wygłoszenia dla niego i kurii rzymskiej rekolekcji wielkopostnych. Widząc obawy o. Bernharda przed tym zadaniem, powiedział: „Odwagi! Głoś bez obawy! Głoś Ewangelię z mocą, tak samo jak zawsze" ${ }^{47}$.

\section{b) Świeccy}

Obok kapłanów adresatami Das Gesetz Christi są świeccy. Autorowi nie chodziło przy tym o rezygnację z naukowego charakteru dzieła lub z posługiwania się fachową terminologią. Było jednak dla niego ważne, aby książka przekazywała treści moralne

\footnotetext{
45 Por. Presbyterorum ordinis, nr 6.

46 Por. B. Häring, Heute Priester sein, dz. cyt., s. 32-38.

47 Tenże, Meine Erfahrung mit der Kirche, Freiburg 1989, s. 85.
} 
w sposób jasny i zrozumiały dla każdego, i dzięki temu przynosiła pożytek wszystkim. Nie chciał, aby zawierała jakiekolwiek treści abstrakcyjne, oddalone od życia. Zadaniem teologii moralnej jest ogłaszanie prawd objawionych, które jednak muszą być „prześwietlane” i podawane w formie odpowiadającej danej epoce. Tylko wtedy będzie ona służyć życiu i królestwu Bożemu. Będzie pomagać świeckim w chrześcijańskim rozumieniu ich powołania jako urzędu oraz w konsekwentnym zmierzaniu do doskonałego życia w Jezusie i z Jezusem. „W Jezusie, w Słowie, które stało się Ciałem, przychodzi Bóg do nas, a my przychodzimy do Niego"48. O. Häringowi chodziło o to, aby człowiek doświadczał pełni życia. Nie kwestionował konieczności norm, niestrudzenie nauczał jednak, że działanie moralne musi być czymś więcej, że wzrok człowieka powinien być zawsze skierowany na sprawy istotne. Wówczas możliwe stanie się doświadczenie pełni radości, a z tego wypłynie motywacja do czynienia dobra. Ma to być więc pomoc w radykalniejszym naśladowaniu Jezusa, ale też w krytycznym spojrzeniu na problemy życia codziennego. W tym znaczeniu teologia moralna ma być chrześcijańską nauką o cnotach $^{49}$.

O. Häring zwracał uwagę, że życie ludzkie nie może być oceniane tylko jednostronnie w odniesieniu do prawa. Na pierwszym miejscu nie powinno stać nawet prawnie uwarunkowane pełnienie woli Bożej; pełnienie jej musi być wynikiem osobowej relacji. Bóg darował swojemu ludowi wszystko w Chrystusie. W Nim objawił też ostateczny, najgłębszy wymiar swojej miłości

48 Tenże, Das Gesetz Christi, dz. cyt., s. 86.

49 Por. tamże, s. 39-41. O. Häring napisał też małą książkę poświęconą tematyce cnót chrześcijańskich: Wege zum Sinn. Eine zeitgemäße Tugendlehre, Graz-Wien-Köln 1997. 
i do niej o. Häring chciał motywować, także ludzi świeckich, swoją pracą naukową.

Ciągle przypominał, że życie chrześcijańskie jest naśladowaniem Chrystusa. Nie może ono jednak być próbą kopiowania Jego życia i postępowania, a nawet próbą zewnętrznego upodabniania się do Niego. Naśladowanie musi koncentrować się na trwaniu w Jego miłości i posłuszeństwie, na pozostawaniu w Nim. Punktem wyjścia jest tutaj chrzest jako włączenie w Chrystusa i na tej bazie całe życie etyczne musi być orientowane na Niego, na Jego dzieło odkupienia. Stąd wszystko, co moralne, ma wymiar biblijny i apostolski.

O. Häring nigdy nie kwestionował tego, że w poprzednich wiekach świeccy współpracowali z kapłanami, ale dokonywało się to zawsze pod ścisłą kontrolą i według wydawanych przez Kościół dyrektyw. Obecnie tego rodzaju współpraca odbywa się na bazie wzajemnego zaufania i kolegialnej kooperacji. Uważał to za pozytywny znak czasu, który przynosi coraz szersze zaangażowanie ludzi świeckich w głoszenie i nauczanie. Poszukują oni prawdy i chcą żyć i działać jako chrześcijanie, dobrze wykształceni i zakorzenieni w wierze i moralności. Dlatego nazywał ten czas wielkim czasem apostolatu świeckich.

Doświadczamy ogromnego przebudzenia się ochrzczonych i bierzmowanych, którzy zachwycają się nauką św. Pawła o powszechnym kapłaństwie. Radośnie gromadzą się wokół ołtarza, przeżywają spotkanie eucharystyczne i czują się współodpowiedzialni za królestwo Boże. Eucharystia stanowi punkt szczytowy wiary i wychowania religijnego. W niej ukazuje Jezus, że żył, cierpiał, umarł i zmartwychwstał dla nas i że nadal jest $\mathrm{z}$ nami. To wzbudza w nas wdzięczność i radość i to przekazujemy dalej. W Eucharystii i w pozostałych sakramentach Jezus daje nam 
udział nie tylko w swoim życiu, ale także w swoim posłaniu bycia żywą Ewangelią. W odpowiedzialności każdego za każdego dokonuje się uświęcanie świata ${ }^{50}$.

Jezus przyniósł światu Ewangelię, która wyzwala, leczy, która jest prawdą. Powierzył ją swojemu ludowi. Ten, wdzięczny za nią, musi jednak ciągle na nowo sobie uświadamiać, że jest ona przeznaczona dla wszystkich. Dlatego o. Häring tak stanowczo podkreślał, że nikt nie zdoła w pełni przeżywać tej radości, jeżeli będzie usiłował tę prawdę objawioną zatrzymać tylko dla siebie. Radością trzeba się dzielić. Dlatego świeccy muszą zgłębiać zagadnienia moralne i starać się je zrozumieć w świetle wymogów czasu. Tym samym inspirują też teologów jako gwarantów zachowania depozytu wiary, jako proroków pośród prorockiej wspólnoty Kościoła, jako pośredników pomiędzy Magisterium a ludem do ponownej refleksji ${ }^{51}$.

Ponieważ głoszenie i nauczanie było i jest istotną częścią posłannictwa Kościoła, wspólnota wierzących nie może skupić się tylko na trosce o jedność wiary jej członków, ale musi się starać, aby wszystkie ludy i narody poznały prawdę i w ten sposób weszły do jedności wiary, nadziei i miłości. Jest to więc ewangelizacja, która zawiera wychowanie religijne i wezwanie do bycia świadkiem Jezusa w świecie współczesnym. Wezwanie to skierowane jest do każdego człowieka.

Wzorem św. Pawła o. Häring podkreślał, że wiara jest darem, dlatego wierzący byłby niewdzięcznikiem, gdyby nie usiłował przekazać jej dalej. Rozumiał jednak dobrze, że nie wszyscy

50 B. Häring, Frei in Christus, t. II, dz. cyt., s. 232; tenże, Das Gesetz Christi, dz. cyt., s. 1326-1328.

51 Por. tenże, Frei in Christus, t. II, dz. cyt., s. 261. 
mają możliwość poświęcić całe swoje życie bezpośredniemu głoszeniu Ewangelii. Dlatego nauczał, że każdy członek wspólnoty wierzących ma udział w posłannictwie Kościoła i stąd ponosi odpowiedzialność za najbliższych, którzy zostali mu powierzeni jako mąż, żona czy dzieci; każdy jest odpowiedzialny za przekazywanie i dalszy rozwój wiary ${ }^{52}$.

\section{Wybrane tematy}

Zasadniczo wszystkie tematy teologii moralnej poruszane przez o. Häringa miały orientację pastoralną. Poniżej zostały wybrane tylko najważniejsze, w których ta orientacja wydaje się najbardziej widoczna.

\section{a) Sakrament pokuty}

Obok bezpośredniego głoszenia Słowa i apostolatu pióra o. Häring udzielał się jako spowiednik, zarówno podczas misji, jak i w późniejszym okresie. Jego doświadczenia na tym polu, z czasu pierwszej spowiedzi i późniejszej posługi w konfesjonale, umocniły go w przekonaniu, że natychmiastowa odnowa posługi sakramentu pokuty jest czymś koniecznym. Ogromnym problemem była kwestia szóstego przykazania i związany z nim rygoryzm prowadzący do odmawiania udzielenia rozgrzeszenia. Księża odwoływali się w tej praktyce do postanowień encykliki Casti connubi z 1930 roku.

Doświadczyłem katastrofalnych skutków tego postanowienia podczas moich misji ludowych zaraz po zakończeniu wojny.

52 Por. tamże, s. 232. 
Setki przychodziły do spowiedzi, którym podczas wcześniejszej misji z tego powodu odmówiono rozgrzeszenia. Penitenci czekali godzinami przed moim konfesjonałem, gdy się rozniosło, że o. Häring okazuje w tym punkcie duże zrozumienie ${ }^{53}$.

Sam przyznawał, że zawsze odczuwał wielką radość, widząc penitenta odchodzącego od konfesjonału z ulgą, ale też $\mathrm{z}$ nową motywacją i radością. Dlatego też chciał, aby księża znaleźli w jego teologii moralnej, którą z całego serca pragnął uprawiać dla duszpasterstwa ${ }^{54}$, materiał do przepowiadania chrześcijańskiej moralności, a także pomoc i orientację dla posługi sakramentalnej, szczególnie sakramentu pokuty. Wzorem św. Alfonsa, który będąc $\mathrm{z}$ zawodu adwokatem, usiłował być nim również w posłudze duszpasterskiej - adwokatem człowieka przed Bogiem, a jeszcze bardziej adwokatem przed nadmierną surowością i rygoryzmem w osądzaniu - przyjmował o. Häring postawę pełną miłości, zrozumienia, dobroci i zachęty. Spowiednik według niego musi być lekarzem duszy, który z mądrością, kompetencją i pewnością stawia diagnozę i podpowiada skuteczny środek leczniczy ${ }^{55}$. Zadaniem kapłana jest głoszenie Dobrej Nowiny o królestwie Bożym w każdym czasie i miejscu, a więc także w konfesjonale. Dlatego ma to być wezwanie do pełnego nawrócenia, do odejścia od grzechu i zwrócenia się ku Bogu. Również ta posługa musi objąć całego człowieka, całe jego życie ${ }^{56}$.

53 Tenże, Geborgen und frei, dz. cyt., s. 96.

54 Por. A. Marcol, Profesor Bernhard Häring: teolog moralista: wstępna synte$z a$, „Studia Theologica Varsaviensia” 29 (1991), nr 2, s. 113-123.

55 Por. M. Leitgöb, Bernhard Häring, dz. cyt., s. 57; B. Häring, Ist die Moraltheologie des hl. Alfonsus aktuell?, dz. cyt., s. 50-72.

56 Por. A. Marcol, Profesor Bernhard Häring, dz. cyt., s. 113-123. 
Było dla niego jasne, że ukazywanie granic w postępowaniu etycznym jest konieczne, ale nie może prowadzić do legalizmu. Starał się uwrażliwiać na niebezpieczeństwo odejścia człowieka od Boga, wyrzeczenia się bycia w Chrystusie poprzez zaniechanie naśladowania Go w życiu codziennym. Aby do tego nie doszło, potrzebna jest pomoc w postaci regulacji prawnej. Prawo musi być jednak ukazane w świetle prawdy o stworzeniu i odkupieniu, w świetle miłości obdarowującej. Jest to wyznaczenie granicy, która z jednej strony przestrzega przed śmiercią moralną, grzechem, ale $\mathrm{z}$ drugiej strony ukazuje i przynagla do postępowania według ciągle wylewającej się miłości Bożej ${ }^{57}$.

O. Häring uważał, że należy raczej stosować zbawczy środek miłosierdzia niż broń ostrości. Taka postawa ma stanowić centrum życia chrześcijańskiego ${ }^{58}$. Nigdy nie lekceważył ani nie odrzucał prawa. Uważał je za konieczne, bo każda wspólnota potrzebuje odpowiedniej regulacji. Musi ono jasno i wyraźnie określać granice i cel postępowania etycznego. Przy tym jednak podkreślał, że najważniejszy jest i musi pozostać konkretny człowiek. Dlatego domagał się „ludzkiego” stosowania norm, ustaw, przepisów i przykazań. Był całkowicie przekonany, że mogą zaistnieć i obiektywnie istnieją takie sytuacje, w których nie może mieć miejsca nic innego jak tylko miłosierdzie i to ono musi stać się prawem działania. Jest to zasada poprawnie rozumianej oikonomii ${ }^{59}$.

Również w tym temacie dominuje chrystocentryzm. O. Häring ukazywał to nie tylko w teorii, ale sam starał się jako spo-

57 Por. B. Häring, Das Gesetz Christi, dz. cyt., s. 39-40.

58 Por. tenże, Moraltheologie für das dritte Jahrtausend, Graz-Wien-Köln 1999, $32 \mathrm{n}$.

59 Por. M. Leitgöb, Bernhard Häring, dz. cyt., s. 75. 
wiednik być miłosiernym ojcem, który w imieniu Jezusa przepowiada zbawienie i uzdrowienie. „Grzeszne oddalenie zostaje przezwyciężone przez Emmanuela, przez Boga z nami, który przynosi nam na nowo miłość Ojca"60. Chrystus jest Odkupicielem. Obdarza zbawieniem, dokonuje pojednania całej ludzkości z Ojcem. Przezwycięża i uwalnia od rozłąki, którą przyniósł grzech. Uzdalnia człowieka do dania odpowiedzi miłości na miłość Boga i zarazem otwiera mu możliwość przejęcia odpowiedzialności za całe jego życie. „Odpowiedź, jaką daje Jezus w naszym imieniu, została potwierdzona Jego krwią, krwią nowego i wiecznego przymierza (...) Jego odpowiedź jest stwórcza, z niej wychodzi nowa ziemia i nowe niebo" ${ }^{61}$.

Chrystus wstawia się za każdym człowiekiem, ale to człowiek musi realizować w swoim codziennym życiu daną przez Niego w jego imieniu odpowiedź Bogu. Jezus jest Słowem, wcieloną odpowiedzią, pośrednikiem, odkupicielem, pojednaniem, wyzwolicielem, posłanym przez Boga, wiernym, który jest całkowicie wolny dla miłości. Dlatego o. Häring nazywał sakrament pokuty miejscem spotkania $\mathrm{z}$ tą miłością ${ }^{62}$.

W swoim nauczaniu odnośnie do tego sakramentu często odwoływał się do św. Alfonsa jako wzoru postępowania pastoralnego. Podkreślał więc, że spowiednik ma być w konfesjonale wiernym odbiciem miłosiernego Ojca. Ma urzeczywistniać uzdrawiającą miłość Jezusa, a nie nakładać zbyteczne ciężary. Niestrudzenie starał się o zachowanie złotego środka pomiędzy ekstremalnym rygoryzmem a laksyzmem. Pomocą była mu

60 B. Häring, Das Gesetz Christi, dz. cyt., s. 349.

61 Tenże, Frei in Christus, t. I, dz. cyt., s. 76.

62 Por. tenże, Geborgen und frei, dz. cyt., s. 128-129. 
w tym przypadku zasada epikei, którą proponował i stosował już św. Tomasz, a potem św. Alfons. Niestety, jej znaczenie zostało zapomniane w XIX wieku. Szanując obowiązywalność ogólnych norm prawnych, o. Häring nauczał, że w szczególnych przypadkach musi istnieć w pełni odpowiedzialna możliwość takiego postępowania, które będzie odpowiadać wymogom sprawiedliwości ${ }^{63}$. Podobnie jak św. Alfons uważał, że nie ma przypadków beznadziejnych, ale że każdy człowiek jest wartościowy i waż-

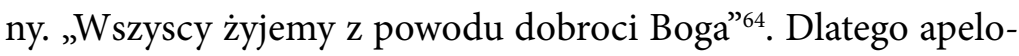
wał do spowiedników, aby tam, gdzie zachodzi potrzeba i możliwość, stosowali jak największą łagodność. Przestrzegał jednak i przed drugą skrajnością.

Sam praktykował w sakramencie pokuty łagodność i uważał, że jeżeli spowiednik trzyma się kurczowo przepisów, aż do odmówienia udzielenia rozgrzeszenia, staje się winny zahamowania u penitenta wzrostu jego doskonałości. Kto usiłuje stosować ostro przepisy prawne, a nie akcentuje prawa łaski i życia w Chrystusie, ten nie dochowuje wierności nauce Biblii - o. Häring ma tutaj na myśli przede wszystkim nauczanie św. Pawła, ale też św. Alfonsa $^{65}$.

\section{b) Ekumenizm}

Doświadczenia życiowe doprowadziły o. Häringa do przekonania o słuszności oraz konieczności ekumenizmu. Z wyznaniem ewangelickim spotkał się już podczas studiów w Tybindze. To uzmysłowiło mu konieczność orientacji chrystologicznej

63 Por. tenże, Das Gesetz Christi, dz. cyt., s. 303.

64 Tenże, Geborgen und frei, dz. cyt., s. 71.

65 Por. tenże, Ist die Moraltheologie des hl. Alfonsus aktuell?, dz. cyt., s. 50-72. 
(solus Christus) i biblijnej (sola scriptura). Zetknięcie z Kościołem prawosławnym miało miejsce przede wszystkim na terenie Rosji podczas wojny. Te spotkania nauczyły go szerszego spojrzenia i posługiwania się Biblią, nie żeby ją cytować, lecz aby odkrywać sens jej przesłania. Nauczył się nowego rozumienia znaczenia łaski i prawa. Ze szczególnym zainteresowaniem śledził stosowanie praktyki oikonomii. Wszystkie te doświadczenia miały wpływ na jego nauczanie i przepowiadanie ${ }^{66}$.

Sobór dodał mu jeszcze odwagi do wzmożonej refleksji ekumenicznej. Nawiązał liczne kontakty ze wspólnotami pozakatolickimi. Zaowocowało to pogłębieniem jego doświadczenia i powiązania z Kościołem powszechnym. Uważał, że obecny czas wzywa do pełnej jedności Kościoła. Chrześcijanie nie mogą współczesnemu światu proponować niezgody czy nienawiści. Wspólna walka przeciw duchowi podziałów jest znakiem jednego, świętego, katolickiego i apostolskiego Kościoła. Stąd też życie moralne musi wypływać ze świętych misteriów, z przeżywania ofiary Chrystusa, z sakramentów.

W tym kontekście o. Häring patrzył z troską na problemy związane z interkomunią i zagadnieniem małżeństw mieszanych. Stanowią one według niego poważne wyzwanie dla ekumenizmu i teologii moralnej. Aby mu sprostać, teologia moralna musi być budowana na mocnym fundamencie ekumenicznego myślenia. Odnosi się to także do kształcenia przyszłych pokoleń. Pod uwagę trzeba brać zarówno teologię dogmatyczną, jak i moralną, tradycje Kościoła wschodniego i zachodniego, ewangelickiego i rzymskokatolickiego, oraz wierność i wolnośćc ${ }^{67}$. Rozbrzmiewa

66 Por. M. Leitgöb, Bernhard Häring, dz. cyt., s. 43.

67 Por. B. Häring, Frei in Christus, t. II, dz. cyt., s. 308-313. 
w tym wezwanie do medytacji, do ciągłego pogłębiania życia wewnętrznego. O. Häring był przekonany, że im bardziej obecny czas naznaczają różnego rodzaju niepokoje, tym bardziej wszyscy wierzący muszą pozostawać złączeni we wspólnej wierze w zmartwychwstanie i paruzję Chrystusa.

W wierze chrześcijańskiej uwielbiamy Boga, który jest Ojcem wszystkich, składamy pokłon Jezusowi Chrystusowi, który jest dla wszystkich wyzwalającą prawdą; oddajemy się Duchowi prawdy, który chce wszystkich doprowadzić do prawdy i jedności. Dlatego gorliwość o jedność chrześcijan stanowi zasadniczą część naszej postawy wiary i zarazem wewnętrzny wymóg prawdy wiary ${ }^{68}$.

Dlatego ekumenizm jest największą otwartością na prawdę. Musi być ona poszukiwana przez wszystkich, bo to daje największą szansę na jej pogłębienie i doświadczenie. Ekumenizm uważa więc o. Häring nie tyle za wyraz wiary w jednego Boga, ile za konieczną drogę, aby lepiej poznać i pojąć historię zbawienia i uniwersalną prawdę o nim. Za podstawę czynnego ekumenizmu przyjmuje Pismo Święte, ale najważniejszą rolę odgrywa asysta Ducha Świętego, który każdego oświeca i kieruje, wzywa do otwartości na swój głos.

Prawdy te są głoszone przez Kościół w mocy Ducha. Dlatego konieczna jest jedność i wierność Kościołowi ${ }^{69}$. Tę drugą ujmował jako wierność swojemu Kościołowi, ale w ramach absolutnej wierności wobec testamentu Jezusa, „aby wszyscy stanowili jedno". Nie popierał apologetycznego punktu widzenia, że wszyscy muszą się nawrócić i wejść na nowo w pełną jedność z Kościołem

\footnotetext{
68 Tamże.

69 Por. tenże, Das Gesetz Christi, dz. cyt., s. 1326-1328.
} 
rzymskokatolickim - przywołuje tu możliwość jedności w różnorodności ${ }^{70}$. Konieczne jest jednak nawrócenie zarówno w wymiarze indywidualnym, jak i wspólnotowym; nawrócenie do Chrystusa, bo On jest drogą do Ojca i drogą do jedności wszystkich ludzi. Taka postawa musi charakteryzować cały Kościół. O. Häring uważał, że podziały nie wynikają z racji prawdy, a więc ekumenizm nie jest dla niej zagrożeniem; podziały wynikają raczej z braku odwagi i uczciwości we wspólnym jej poszukiwaniu. Dlatego podkreślał, że wspólnota chrześcijańska, która nie jest na poważnie zainteresowana poszukiwaniem jedności, nie może być miejscem, w którym chrześcijanin może żyć ze spokojnym sumieniem. Konieczna jest przemiana. Nikt nie może odpowiedzialnie wyznać, że Jezus jest Panem, jeżeli nie usiłuje wprowadzać jedności pomiędzy Jego uczniami, jeżeli nie wypełnia Jego testamentu.

Chrystus w swojej dobroci obdarzył ludzkość tęsknotą za jednością. Dlatego teologia moralna nie byłaby wierną sobie i swojemu powołaniu, gdyby nie poświęcała się wyzwaniom ekumenizmu. Według o. Häringa, nie wystarczy jednak tylko myśleć i mówić o ekumenizmie. Aby uzyskać jedność, konieczne jest ekumeniczne patrzenie, wsłuchiwanie się i przede wszystkim niestrudzone działanie na każdym kroku. Ważną rolę odgrywa w tych wysiłkach synteza kontynuacji z twórczą wolnością. Nie wolno więc - jak się wyraził - „sprzedać” swojej wolności na rzecz przeszłości, ale pamiętając o przeszłości i tradycji, patrzeć ufnie i odważnie w przyszłość, nawet jeżeli droga do celu wydaje się jeszcze długa ${ }^{71}$.

70 Por. tenże, Frei in Christus, t. II, dz. cyt., s. 292-293.

71 Por. tamże, s. 279; także s. 17-21. Ekumenizmowi poświęca rozdział szósty drugiego tomu Frei in Christus, s. 266-314. 


\section{c) Wolność i pokój}

Bardzo ważnym tematem było dla o. Häringa zagadnienie wolności i pokoju. Sam doświadczył, czym jest wojna ${ }^{72}$, dlatego uważał, że posługa na rzecz pokoju musi być centralnym punktem jego pracy. Przekonanie to objęło zarówno płaszczyznę indywidualną, a więc relacje osoby do osoby, jak i ogólnoludzką, to znaczy wszystkie wymiary życia społecznego. Według niego, chrześcijanie muszą stawać się pośrednikami pojednania w grupie, w społeczeństwie, w Kościele ${ }^{73}$.

Głód wolności, przekonanie, że musimy jeszcze bardziej łączyć się na rzecz wyzwolenia i zachować czujność odnośnie do wierności, należą do znaków czasu. Tylko w otwartym dialogu, w wymianie doświadczeń i przemyśleń, we wspólnej wierności Chrystusowi, damy odpowiedź na wymogi czasu ${ }^{74}$.

O. Häring uważał, że katolicy mogą i muszą uczyć się od innych wyznań, że muszą stawiać czoła problemom i odcinać się od wielu niepoprawnych i nieprawdziwych tez czy dawanych odpowiedzi. Te poglądy $\mathrm{w}$ tamtym czasie były przyjmowane raczej ze sceptycyzmem, chodziło jednak o wzajemne ubogacanie się. Dlatego pielęgnował kontakty z Bratem Rogerem z Taizé czy z patriarchą Konstantynopola Atenagorasem. Stąd wynikło jego szczególne przekonanie o słuszności oikonomii ${ }^{75}$.

72 „Doświadczyłem oczywiście nie tylko otchłani grzechu, ale także wiele dobra i serdeczności ze strony ludności rosyjskiej i polskiej, którym zawdzięczam moją wolność i moje życie”; tenże, Als es um’s Überleben ging. Kriegserinnerungen eines Priesters, Graz-Wien-Köln 1977.

73 Por. tenże, Geborgen und frei, dz. cyt., s. 73-75.

74 Tenże, Frei in Christus, t. I, dz. cyt., s. 18.

75 Por. tenże, Geborgen und frei, dz. cyt., s. 63. 
Ważnym i pomocnym doświadczeniem było spotkanie z teologią wyzwolenia i licznymi „grupami podstawowymi”. Wyniósł z niego przekonanie, że wolność, wyzwolenie i uzdrowienie są czymś nierozerwalnie ze sobą związanym. Te punkty usilnie akcentował w swojej teologii moralnej. Odrzucał więc bardzo zdecydowanie moralizowanie, a starał się ukazywać wiarę, która uzdrawia. Wszystkie te kontakty i doświadczenia powodowały dalsze dojrzewanie jego kapłaństwa i posługi duszpasterskiej, ale zawsze w wierności, wolności i kontynuacji. Dlatego mógł z przekonaniem napisać, że każdy rozdział jego teologii moralnej - ma tutaj na myśli Frei in Christus - zawiera te treści albo w sposób bezpośredni, lub przynajmniej pośredni ${ }^{76}$.

Z wiarą wyznawał, że Jezus jest jednym spośród nas, ale też Synem Bożym, że jest prorokiem, który ukazuje drogę pokoju i wolności bez użycia przemocy, ale też demaskuje fałszywych proroków, którzy zniekształcają prawdziwy obraz Boga i religii. Słusznie zauważał, że chrześcijanin jest człowiekiem Wielkanocy, zakorzenionym w pokoju, który pochodzi od Zmartwychwstałego $^{77}$. Poglądy te znalazły odbicie w konstytucji soborowej Gaudium et spes $^{78}$. Jako sekretarz redakcji tego dokumentu zabiegał o zamieszczenie treści dotyczącej ogólnego powołania chrześcijańskiego na rzecz pokoju i wolności. Zawsze uważał to wezwanie za szczególny znak czasu. Temu tematowi poświęcił też wiele artykułów, referatów, jak i książkę Von der Heilkraft der Gewaltfreiheit. Apelował, gdzie tylko mógł, aby to szczególne powołanie było najpierw pielęgnowane przez każdego człowieka osobiście.

76 Por. tenże, Heute Priester sein, dz. cyt., s. 23-24; tenże, Frei in Christus, t. I, dz. cyt., s. 17-21.

77 Por. tenże, Das Gesetz Christi, dz. cyt., s. 1326-1328.

78 Szczególnie chodzi tutaj o część II, rozdział V. 
Zaliczał do niego również zdolność przebaczenia zarówno sobie samemu, jak i innym. Myślał tutaj o przebaczeniu z całego serca, bo tylko takie może przynieść uzdrowienie i pobudzić wzajemną miłość, czyniąc świat lepszym ${ }^{79}$.

Myślą wybiegał też w przyszłość, do nowych pokoleń, które muszą w pełnej świadomości ciągle na nowo opowiadać się za wolnością. Wolność rozumiał jako bezwarunkową wierność Chrystusowi, bo On jest najwyższą prawdą i wiernością. Usilnie podkreślał jedność między prawdą a wolnością. Obie są darem Boga i zarazem zadaniem powierzonym człowiekowi. Dlatego też teologię moralną ujmował jako wierne miłowanie i czynienie prawdy, która pochodzi od Chrystusa i która wszczepia w Niego. Do tego konieczna jest troska o dar poprawnego rozeznawania duchów. Temu tematowi poświęcił sporo miejsca w drugim tomie Frei in Christus ${ }^{80}$.

d) Rodzina i małżeństwo

O. Häring miał szczęście doświadczyć prawdziwego życia i ciepła rodzinnego ${ }^{81}$. Jego rodzice usiłowali żyć w partnerstwie budowanym na wierze, wzajemnej miłości i szacunku. Doświadczenie to warunkowało jego późniejsze myślenie i nauczanie o małżeństwie i rodzinie; traktował je zawsze jako jedność. Pomocą służyła mu też socjologia. Małżeństwo uważał za instytucję ustanowioną przez Boga, który ma wobec niej swój plan zbawczy, domagający się jednak ludzkiej wierności. Bóg chce istnienia małżeństwa i rodziny jako wspólnoty życia i miłości. Dlatego

\footnotetext{
79 Por. B. Häring, Geborgen und frei, dz. cyt., s. 67-68.

80 Por. tenże, Frei in Christus, t. II, dz. cyt., s. 17-21.

81 Por. M. Leitgöb, Bernhard Häring, dz. cyt., s. 17.
} 
miłość jest środkiem i celem małżeństwa. Tam gdzie zajmuje ona naczelne miejsce, dokonuje się przezwyciężenie egoizmu zarówno indywidualnego, jak i egoizmu we dwoje ${ }^{82}$.

Małżeństwo i rodzinę o. Häring uważał za miejsce, gdzie osoba ludzka realizuje się w swoim wymiarze cielesnym i duchowym, moralnym i religijnym; gdzie wzajemna miłość przynosi owoc w postaci nowego życia i tym samym przyczynia się do odnowy i wzrostu społeczeństwa. Stanowi antidotum na samotność i skostnienie; przeciwstawia się skrajnemu indywidualizmowi.

Jezus uświęcił rodzinę przez swoje narodzenie i życie w niej. Małżeństwo i rodzina, wyniesione do rangi sakramentu, nie tylko łączą mężczyznę i kobietę w jedno, ale przede wszystkim uświęcają i czynią małym Kościołem całość ich życia i postępowania, łącznie z potomstwem. O. Häring, powołując się na naukę Soboru Watykańskiego II, nauczał, że rodzina jest szczególnym powołaniem i drogą zbawienia. Oczywiście wiedział o problemach i krzyżach w rodzinach. Dlatego za bardzo ważne zadanie uważał działalność pastoralną na rzecz rodziny. Musi ona znajdować się w samym centrum troski duszpasterskiej Kościoła. Uważał, że ciągle trzeba mówić o randze, ale i obowiązkach wobec rodziny. Całe duszpasterstwo musi ją brać pod uwagę.

To rodzina przynosi dziecko do chrztu i bierze na siebie obowiązek wychowania go w duchu wiary; to rodzina decyduje o przyjęciu przez nie Komunii św. i przygotowuje do tego. Rodzice są pierwszymi, chociaż nie jedynymi, duszpasterzami swojego dziecka; to oni prowadzą je do Chrystusa. Duszpasterstwo - o. Häring ma tutaj na myśli przede wszystkim duszpasterstwo stanowe - nie może wprowadzać podziałów, rozrywać

82 Por. B. Häring, Frei in Christus, t. II, dz. cyt., s. 503. 
rodziny, ale ma ją wzmacniać. Parafia natomiast ma za zadanie wspierać rodzinę, umacniać jej jedność i stawać się sama rodziną parafialną ${ }^{83}$. W tym duchu proponował spotykanie się rodzin w kręgach, aby wzajemnie się ubogacać, wspierać i motywować.

Podkreślał też ważność odpowiedniego przygotowania do małżeństwa. Uważał, że mają to być nie tylko sporadyczne kursy przynoszące wskazania, a już z całą pewnością nie chodziło mu o wyakcentowanie problematyki związanej z szóstym przykazaniem, ale o zwrócenie uwagi przyszłych małżonków na konieczność kształtowania całego życia we wszystkich jego wymiarach w duchu chrześcijańskim ${ }^{84}$. Ponieważ małżeństwo jest powołaniem, narzeczeni muszą się pytać, czy jest to ich droga i czy mają ku temu odpowiednie uzdolnienia. Zamiar zawarcia związku małżeńskiego nie może być warunkowany bogactwem, pozycją społeczną czy też wyglądem zewnętrznym, ale zdolnością do miłości, wierności i szacunku. Ważnym pytaniem jest, czy partner/partnerka ma odpowiednie predyspozycje do bycia dobrym mężem/dobrą żoną ${ }^{85}$.

Kościół natomiast musi dołożyć wszelkich starań, aby chronić rodzinę przed rozbiciem, osłabieniem, przed błędnymi ideologiami czasu, polityki czy państwa, które nie szanują świętości i nierozerwalności małżeństwa i rodziny. Jego obowiązkiem jest również upominać się o należyte prawa materialne, socjalne, moralno-religijne dla całej rodziny. Państwo jako takie musi gwarantować rodzinie należne jej miejsce, prawa i nie tylko ich

\footnotetext{
83 Por. tenże, Das Gesetz Christi, dz. cyt., s. 932-933.

84 Por. M. Leitgöb, Bernhard Häring, dz. cyt., s. 88.

85 Por. tenże, Frei in Christus, t. II, dz. cyt., s. 505-506.
} 
konsekwentnie przestrzegać, ale też stać na straży ich realizacji przez wszystkich obywateli. To należy do jego obowiązków.

W swoim nauczaniu o. Häring wskazywał również na obowiązki i odpowiedzialność małżonków i rodziców wobec siebie nawzajem: odpowiedzialność za wierność, solidarność, miłość. Już na początku swojej działalności, mimo panującego wówczas rygoryzmu, podkreślał wzorem św. Alfonsa, że każdy akt małżeński jest dobry, dopóki jest wyrazem miłości małżeńskiej albo służy zachowaniu wierności. W tym kontekście przestrzegał spowiedników, aby unikali nierozważnych pytań odnośnie do stosunków seksualnych ${ }^{86}$. Apelował do rodziców, aby poważnie traktowali swoje obowiązki wobec dzieci, aby wzięli na siebie troskę o ich wychowanie, w tym religijne, aby byli dla nich pomocą w wyborze szkoły czy zawodu. Przypominał im, że mają służyć swoim dzieciom pomocą w aktywnym przejmowaniu odpowiedzialności za ich przyszłe samodzielne życie. Nie zapomniał również wymienić obowiązków dzieci wobec rodziców. Zaliczał do nich posłuszeństwo, miłość i wdzięczność. Wspomniał też o szkole, jej roli i zadaniach ${ }^{87}$.

\section{Zakończenie}

Rok przed swoją śmiercią (3 lipca 1998) o. Häring opublikował książkę Meine Hoffnung für die Kirche. Kritische Ermutigungen. Zawarł w niej krytyczne spojrzenie na siebie samego jako teologa moralistę, na swoje nauczanie i tematy, którymi się zajmował. Również tutaj podkreślił, że teologia moralna jest i musi pozostać

86 Por. tenże, Geborgen und frei, dz. cyt., s. 95.

87 Por. tenże, Das Gesetz Christi, dz. cyt., s. 936-961. 
przepowiadaniem podstawowych prawd dostosowanych odpowiednio do danego czasu. Wprawdzie różni się ona od bezpośredniego głoszenia kazań i duszpasterstwa, jednak pozostaje przyporządkowana w sposób istotny duszpasterstwu w czasie i dla czasu jako ożywcza służba w Kościele. Wypełnia ona swoje zadanie, gdy potrafi zrozumieć palące potrzeby współczesnego człowieka. Dlatego o. Häring tak zdecydowanie podkreślał, że teolog musi najpierw wsłuchiwać się w głos Boga, ale także ludzi, szczególnie ubogich, a przy tym mieć szerokie horyzonty myślowe i być wyposażony w wiele „anten”, aby w całej wielorakiej rzeczywistości dawać odpowiedź na poszczególne tematy, ukazując też ich wzajemne powiązanie. Musi mieć dobre poczucie wartości i posługiwać się odpowiednio językiem swojego czasu; musi ciągle na nowo analizować problemy wiary, wolności, pokoju. Nie liczy się tylko apologetyka, ale przede wszystkim dialog i odważne spojrzenie prawdzie w oczy. Jeżeli natomiast przestanie słuchać i nauczać, to zatraci sens swojego powołania, rozminie się z życiem i ze swoimi adresatami ${ }^{88}$.

Teologia musi regularnie robić sobie rachunek sumienia i zadawać pytanie: czy rzeczywiście głosi łaskę przychodzącego królestwa Bożego? Czy poprawnie rozumie naukę o nawróceniu na wzór Chrystusa jako ukierunkowanie na królestwo Boże, jako wchodzenie do wspólnoty niosącej panowanie miłości? Dlatego tak ważne jest, aby teolog żył w jedności z Kościołem, aby wsłuchiwał się w jego głos, głos Magisterium, świętych, wprowadzających pokój, ale też w wołanie całego ludu ${ }^{89}$.

88 Por. tenże, Meine Hoffnung für die Kirche, dz. cyt., s. 32-33.

89 Por. tenże, Ist die Moraltheologie des hl. Alfonsus aktuell?, dz. cyt., s. 50-72. 
Wzorem dla całego nauczania o. Häringa pozostawał Jezus, który głosił swoją naukę z mocą i jednoznacznie oraz wewnętrznie się z nią utożsamiał. Nie zrywał przy tym jednak więzi z tradycją. Bardzo stanowczo natomiast wzywał do nawrócenia, do uznania pełni władzy Boga nad sercem i wszystkimi sferami życia ludzkiego. Po tej samej linii poszedł św. Paweł jako Jego wierny apostoł i głosił z mocą naukę o zbawieniu i życiu w Chrystusie. Również on doceniał wypracowane wcześniej poglądy, ale akcentował wypełnianie się najgłębszych pragnień i oczekiwań przez włączenie się w Chrystusa, przez poddanie się Jego panowaniu w miłości. $Z$ tego wynikało wezwanie do prowadzenia nowego życia i wyzbycia się starego zaczynu grzechu; życie moralne musi wypływać z obdarowującej i kochającej woli Boga. Warunkiem owocnego głoszenia jest osobiste przeżycie i doświadczenie Ewangelii ${ }^{90}$.

W swoim nauczaniu o. Häring podkreślał jedność wiary i życia moralnego, tajemnicy zbawienia i prowadzenia życia, działania łaski Bożej i miłości wypełniającej człowieka. Przy tym zwracał uwagę na pokorę Boga, który dla człowieka zgodził się na krzyż. Tak postępował św. Alfons i taki sposób uważał za słuszny i stosował o. Häring. Usiłował w nauczaniu i głoszeniu Dobrej Nowiny budzić radość, pogłębiać wiarę, uzasadniać wspólnotę wiary i religii. Zwracał uwagę, aby jego głoszenie dokonywało się też w imieniu ludzi odrzuconych, wzgardzonych, „nieczystych". Chciał patrzeć na nich oczyma Jezusa. Wskazywał, że stąd płyną nowe i silne impulsy do nowego życia w duchu chrześcijańskim, w wolności dzieci Bożych ${ }^{91}$.

90 Por. tenże, Frei in Christus, t. II, dz. cyt., s. 234 n.

91 Por. tenże, Die Neuheit des sittlichen Lebens, w: tenże, Die gegenwärtige Heilsstunde, dz. cyt., s. 25-33. 
W wyżej wspomnianej książce wymienił cały szereg tematów, które według niego są i pozostaną istotne dla całego nauczania moralnego: życie wolne w Chrystusie, solidarna wolność, wolność uzdrawiająca, kolegialność, a także sakrament pokuty, dialog ekumeniczny, inkulturacja, pokój czy rodzina. Wybiegał także myślą w przyszłość i rozważał rolę i zadania świeckich w Kościele, w tym kobiet, łącznie z pytaniem o możliwość udzielania im święceń kapłańskich. Zastanawiał się nad problemem i kryzysem powołań kapłańskich w powiązaniu z celibatem. $\mathrm{Z}$ troską patrzył na rodzinę i małżeństwo oraz ich problemy, w szczególności podkreślał konieczność odpowiedniego duszpasterstwa dla ludzi rozwiedzionych i żyjących w nowych związkach.

Słusznie wskazywał więc tematy, które dziś, po 20 latach, są nadal aktualne, rozważane, dyskutowane i poszukiwane są dla nich sprawiedliwe, odpowiedzialne i odważne rozwiązania. 
A. Uniwersytet Papieski T.6. Jana Pawła II 